\title{
Comparative study of the egg quality of Bhutanese indigenous strains reared under different production systems
}

\author{
N Dorji* \\ Department of Animal Science, College of Natural Resources, Royal University of Bhutan, Bhutan
}

A total of 68 Bhutanese indigenous chicken eggs were collected from Research station (imitating improved management) and villages (farmer's management) to estimate the egg quality. The weight of eggs sampled from Research farm was comparatively heavier $(50.63 \mathrm{~g} \pm 5.04)$ than the extensive farmer's system $(45.94 \pm 5.68)$. The yolk index was higher $(39.85 \% \pm 5.69)$ in village management than that of improved management $(41.93 \% \pm 3.16)$. Moreover, the shell quality of eggs laid by hen reared at Research station was better (shell thickness $=0.33 \pm 0.03$, specific gravity $=1.14 \pm 0.07$ ) than its counterpart management conditions (shell thickness = $0.31 \pm 0.03$, specific gravity $=1.10 \pm 0.09$ ). On contrary, Haugh unit and egg shape index were decreased from 74.45 \pm 2.85 (farmer's management) to $72.67 \pm 1.53$ (Research station) and $74.09 \% \pm 3.85$ (farmer's management) to $71.54 \% \pm 2.86$ (Research station), respectively. Significance of difference were observed for egg weight, shape index and Haugh Unit between different management conditions $(p<0.05)$. However, there were no significant difference in egg volume, egg shell quality, yolk index and yolk and shell percent $(p<0.05)$.

The traditional backyard system of rearing indigenous birds predominant in Bhutan and is a typical characteristics of an agrarian nation. In Bhutan, chicken retains its dominance in the country's poultry sector and it also outnumbers any livestock species population (Dorji and Gyeltshen 2012). This is because they are kept for socio-cultural importance, basically for eggs (Dorji et al. 2012; Dorji and Gyeltshen 2012). Productive performances of the traditional birds are low but their meat and eggs have better taste and flavor (Dorji and Gyeltshen 2012). Moreover, indigenous chickens are locally adapted (Dorji et al. 2012), highly productive with improved management practices and importantly reservoir of genetic resources for unpredicted future breeding requirements (Dorji et al. 2011).

Egg is one of the most essential cheap sources of protein in human diet all across the globe. Quality of an egg ascertains the success of a poultry business because it is associated with the acceptability among the consumers (Rajkumar et al. 2009). Based on consumer's choice, the eggs are categorized in respect of shell colour, albumen quality and yolk characteristics. Most of the table eggs in developing countries derive from extensive commercial production system. However, there is scope to improve the productivity of local indigenous poultry birds through better management practices (Alewi et al. 2012). Alewi et al. (2012) further suggested to examine physical egg qualities of Bhutanese indigenous chickens reared under farmer's management and compare with improved management. Thus, the present study was undertaken to compare physical traits of eggs collected from village and Research farm.

A total of 68 eggs from the indigenous chicken were collected of which 24 and 44 eggs were sampled from Research station and villages, respectively. The eggs were not older than five days. The eggs were screened for any damage (including the cracks) by candling method manually. Edible oil was used to clean the dirty eggs. The age of the traditional hens ranged from 1 - 2 year old during the study.

The sources of egg samples for extensive production system included were Tsirang (Tsholingkha, Dunglagan and Semjong villages), Punakha (Zomi, Laptshakah and Walakha villages) and Daga (Dagapela) districts. These birds are kept for maintaining the flock and are characterized by poor management conditions (Dorji and Gyeltshen 2012). They find their own 
food which mainly consists of agricultural wastes, worms, insects and grubs.

Research station/farm (Bumthang district) has been rearing indigenous birds under improved management conditions. The birds were reared under deep litter system with proper biosecurity measures. The birds were provided with layer feed and treated against the worms. Feeders and drinkers were provided which were cleaned before providing feed and water to the birds. The birds were fed twice a day. The layer feed contains crude protein, metabolizable energy and calcium value of $15.70 \%, 2,883-2,900 \mathrm{Kcal}$ and $4 \%$ respectively.

To evaluate the egg quality of Bhutanese indigenous chickens from two different management conditions, data were recorded for egg weight and width and length by digital electronic weighing machine and electronic vernier caliper, respectively. Egg shape index can directly be estimated by the formula:

Egg shape index $=$ (Width of egg) / (Length of egg) $\times 100$

The specific gravity is an indication of shell quality relative to other components and it was determined using the formula suggested by Stadelman and Cotterill (1995):

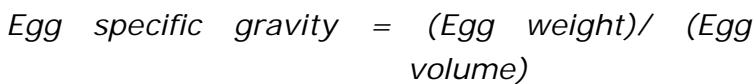

Egg volume was estimated using the method of Romanoff and Romanoff (1949) cited in Al-Obaidi and Al-Shadeedi (2012):

Egg volume $=0.512($ Egg length $)(\text { Egg width })^{2}$

After the examination of exterior quality traits, egg was cracked open. The egg contents were allowed to flow freely on a clean dry petri dish. Immediately, multiple measurements of height were made from several areas of spread inner thick albumen using sensitive electronic vernier caliper as per Silversides and Scott (2001) method. Simultaneously, the height and diameter of the yolk was measured. The yolk was then separated from the rest egg components carefully and weighed by digital electronic weighing machine on a clean dry petri dish. The thickness of egg shell was measured thrice at different position by electronic vernier caliper. The weight of the shell was determined after drying at $55^{\circ} \mathrm{C}$ for three days (Anderson et al. 2004). Evidently, the albumen weight was estimated as:

Albumen weight $=$ Egg weight $-($ Yolk weight + Shell weight)

Haugh unit for individual egg was estimated by Monira et al. (2003):

Haugh Unit $=100 \log \left(\mathrm{AH}-1.7 \mathrm{EWT}^{0.37}+7.6\right)$

where $A H$, Height of thick albumen $(\mathrm{mm})$; EWT, Weight of an egg $(\mathrm{g})$

The percent of three principle egg components were taken as a proportion to egg weight:

Egg component $(\%)=$ (Component weight)/ (Total egg weight) $\times 100$

An Independent Sample T-test (SPSS 16.0) was used to separate the means when significant difference was observed $(p=0.05)$.

The egg phenotype is an important trait in commercial poultry farming because the shapes that are abnormal do not fit in prepackaging. Egg shape and size have direct impact on an economic value. The mean egg weight (EWT) collected under improved management conditions (Research farm) was comparatively heavier than farmer's management (Table 1). Generally, the standard chicken EWT is $61 \mathrm{~g}$ (Arthur and Sullivan 2005) however, the weight may differ from one region to another. For instance, medium EWT for US and Africa is $49-56 \mathrm{~g}$ and $55-65 \mathrm{~g}$, respectively (FAO 2000). Against the US and African standard of EWT, our Bhutanese indigenous chickens (BIC) strains EWT was lighter and as heavier as Kashmir local chickens (I qbal et al. 2009). On the other hand, BIC egg weighed more than Bangladeshi of 35-39g (Sonaiya and Swan 2004), Ethiopian of $38.30 \mathrm{~g}$ (Alewi et al. 2012) and Rajshahi of $40.04 \mathrm{~g} \pm 2.52$ (Islam and Dutta 2010) local birds reared under farmer's management. Our BIC EWT collected from the Research station was lighter than Nigerian local chickens reared at research farm (Isidahomen et al. 2013)

Similarly, egg shape index (ESI) for two different production system was highly significant $(p<$ 
0.01 ). The ESI in this study was higher than local Kei egg of $72.80 \%$ (Alewi et al. 2012) collected from the villages. This implies that our BIC egg is more round than Ethiopian traditional birds. On contrary, the egg from Guwahatti local chickens reared under village system was slightly rounder than BIC eggs (Baishya et al. 2008).

No significant of difference, observed in egg volume between BIC eggs from different sources $(p<0.05)$. Notably, egg volume derived from our experimental birds was higher than Rajshahi local birds of $34.99 \pm 5.72$ (Islam and Dutta 2010). The significance of difference between production systems for specific gravity was not noticed $(p<0.05)$ with the mean of $1.10 \pm 0.09$ and $1.14 \pm 0.07$ sampled from village and improved management, respectively (Table 1 ).

The Haugh unit ( $\mathrm{HU}$ ) derived from the current study was highly significant for two different production system $(p=0.001)$. However, HU score for BIC was comparatively lower than the value of
83.30 in Ethiopian (Alewi et al. 2012) and 80.48 in Guwahatti (Baishya et al. 2008) local birds kept by farmers. On the other, Tanzania local eggs HU estimates was 67.70 (Nonga et al. 2010) which is lower than present study. The average yolk index (YI) estimate was lower than $46.49 \%$ of Ethiopian (Alewi et al. 2012), near to $39.00 \%$ of Guwahatti (Baishya et al. 2008) but higher than $31.60 \%$ of Tanzanian (Nonga et al. 2010) traditional chickens kept free-scavenging.

There were no significant differences between eggs from villages and Research station for yolk percent (YP), albumen percent (AP), shell percent (SP) and shell thickness (STH). The distribution of the YP, AP and SP in current study was in agreement with Ahmadi and Rahimi (2011) review. This probably implies that the BIC kept at Research farm has been not focused on improving the quality of eggs. However, the egg trait parameters range (minimum and maximum measurement) has reduced greatly for BIC kept at Research farm (Table 1).

Table 1. Physical egg qualities of Bhutanese chicken reared under different management system

\begin{tabular}{lllll}
\hline \multirow{2}{*}{ Parameters } & \multicolumn{2}{c}{ Farmer's management } & \multicolumn{2}{c}{ Research station } \\
\cline { 2 - 5 } & Mean $\pm \mathrm{SD}$ & Range & Mean $\pm \mathrm{SD}$ & Range \\
\hline Egg weight $(\mathrm{g})$ & $45.94 \pm 5.68^{\mathrm{a}}$ & $33.93-57.08$ & $50.63 \pm 5.04^{\mathrm{b}}$ & $42.38-60.48$ \\
Egg shape index & $74.09 \pm 3.85^{\mathrm{a}}$ & $65.40-80.69$ & $71.54 \pm 2.86^{\mathrm{b}}$ & $66.79-77.07$ \\
Egg volume $\left(\mathrm{cm}^{3}\right)$ & $42.17 \pm 6.49^{\mathrm{a}}$ & $29.18-61.71$ & $44.52 \pm 5.06^{\mathrm{a}}$ & $32.48-55.47$ \\
Specific gravity $\left(\mathrm{gm} / \mathrm{cm}^{3}\right)$ & $1.10 \pm 0.09^{\mathrm{a}}$ & $0.85-1.57$ & $1.14 \pm 0.07^{\mathrm{a}}$ & $1.07-1.30$ \\
Yolk index & $39.85 \pm 5.69^{\mathrm{a}}$ & $26.40-58.14$ & $41.93 \pm 3.16^{\mathrm{a}}$ & $35.62-50.28$ \\
Haugh unit & $74.45 \pm 2.85^{\mathrm{a}}$ & $64.75-79.72$ & $72.67 \pm 1.53^{\mathrm{b}}$ & $69.79-75.64$ \\
Yolk percentage & $32.66 \pm 3.51^{\mathrm{a}}$ & $25.93-42.05$ & $32.29 \pm 2.56^{\mathrm{a}}$ & $27.09-37.41$ \\
Albumen percentage & $58.20 \pm 3.87^{\mathrm{a}}$ & $48.17-66.40$ & $58.50 \pm 2.85^{\mathrm{a}}$ & $53.94-64.64$ \\
Shell percentage & $9.14 \pm 1.06^{\mathrm{a}}$ & $6.95-11.16$ & $9.21 \pm 0.85^{\mathrm{a}}$ & $8.03-11.15$ \\
Shell thickness $(\mathrm{mm})$ & $0.31 \pm 0.03^{\mathrm{a}}$ & $0.22-0.40$ & $0.33 \pm 0.03^{\mathrm{a}}$ & $0.29-0.46$ \\
\hline
\end{tabular}

Means with different superscript in the same row differed significantly $(p<0.05)$; SD, standard deviation

The result indicates that the birds are under controlled breeding scheme and has influenced over economic traits including the quality of egg (Tharringtom et al. 1999; Anderson et al. 2004). Some egg traits can be improved with short generation and these includes EWT, AH (expressed as HU), shell strength (SPG and STH) and shell colour because of high heritability (Arthur and Sullivan 2005). For example, the increase in EWT has affected the eggs to become more round (Monira et al. 2003; Anderson et al. 176
2004). Similarly, the egg shell quality from research farm has improved (Tharringtom et al. 1999; Anderson et al. 2004) but the STH improvement was not significant $(p=0.11)$ agreeing with Jones and Musgrove (2005) manuscript. Anderson et al. (2004) also concluded based on three historical strains and one current strain of commercial Single Comb White that STH has improved but not significantly $(p<0.05)$. Thus, it may deduce that the selection within these populations has either improved or 
maintained the quality of egg shell (Tharringtom et al. 1999).

There are controversies on importance of bird nutrition on egg quality. Nevertheless, the better shell quality may be explained by availability of required amount of nutrients responsible for shell formation in birds (Ahmadi and Rahimi 2011; Albrecht 2011). Likewise, the commercial feed provided to birds reared under improved management consists of suggested minerals of $4 \%$ calcium (Albrecht 2011 ). It is considered that the STH of egg is an important bioeconomic trait (Alewi et al. 2012) and it should be at least $0.35 \mathrm{~mm}$ to withstand from handling and transportation (Sonaiya and Swan 2004). The mean egg STH of Research farm $(0.33 \mathrm{~mm})$ was thicker than its counterparts with $0.31 \mathrm{~mm}$ (Table 1 ). The egg STH value in current study was higher than local Kei and their crossbred (Alewi et al. 2012) but lower than Indian (Rajkumar et al. 2009) and Morogorian (Nonga et al. 2010) chicken kept at Research farms.

\section{Conclusions}

The results indicate that the difference in management practices and average parental weight possibly explain to difference in egg quality derived. Therefore, improving the rearing conditions would improve the physical egg quality for marketing. However, cost-benefit analysis should be undertaken to optimize the gross profits.

\section{Acknowledgements}

The author acknowledges the funding agency, College Development Fund (College of Natural Resources, Royal University of Bhutan). Further appreciation goes to Research farm and the village farmers for their willingness to provide the egg samples in conducting present study.

\section{References}

Ahmadi F and Rahimi F (2011) Factors affecting quality and quantity of egg production in laying hen: a review. World's Applied Science J ournal, 12: 372-384.

Albrecht HN (2011) Reproductive soundness and egg quality in chickens selected for low and high antibody response. Master of Science in Animal and Poultry Science, Blacksburg, VA.

Alewi M, Melesse A and Teklegiorgis $Y$ (2012) Crossbreeding effect on egg quality traits of local chickens and their crossbreds with Rhode Island Red and Fayoumi chicken breeds under farmer's management conditions. Journal of Animal Science Advances, 2: 69-705.

Al-Obaidi FA and Al-Shadeedi SM (2012) Egg structural characteristics of Pygmy Cormorant (Microcarbo pygmaeus). Research Opinions in Animal and Veterinary Sciences, 2: 4-6.

Anderson KE, Tharrington J B, Curtis PA and Jones FT (2004) Shell characteristics of eggs from historic strains of single comb White Leghorn chickens and the relationships of egg shape to shell strength. International J ournal of Poultry Science, 3: 17-19.

Arthur JA and O'Sullivan N (2005) International Hatchery Practice. 19: 7-9. Available at: http: //www. positiveaction. info/pdfs/articles /hp19.7p7.pdf.

Baishya D, Dutta KK, Mahanta JD and Borpujari RN (2008) Studies on certain qualities of different sources of chicken eggs. Tamil Nadu Journal of Veterinary \& Animal Sciences, 4: 139-141.

Dorji N, Daungjinda M and Phasuk Y (2011) Genetic characterization of Thai indigenous chickens compared with commercial lines. Tropical Animal Health \& Production, 43(4): 779-85.

Dorji N, Daungjinda $M$ and Phasuk $Y$ (2012) Genetic characterization of Bhutanese native chickens based on an analysis of Red Junglefowl (Gallus gallus gallus and Gallus gallus spadecieus), domestic Southeast Asian and commercial chicken lines (Gallus gallus domesticus). Genetics and Molecular Biology, 35: 1415-4757.

Dorji N and Gyeltshen T (2012) Characterisation of family poultry production in $\mathrm{Haa}$ and Mongar districts of Bhutan. Livestock Research for Rural Development, 24: 155.

FAO (2003) Egg marketing - A guide for the production and sale of eggs. FAO Agricultural services bulletin. 150, Rome.

Jones DR and Musgrove MT (2005) Extended storage on egg quality factors. Poultry Science, 84: 1774-1777. 


\section{Egg quality of Bhutanese indigenous chicken}

Iqbal S, Pampori ZA and Hasin D (2009) Carcass and egg characteristics of indigenous chicken of Kashmir (Kashmir favorella). Indian Journal of Animal Research, 43: 194-196.

Isidahomen CE, Njidda AA and Olatunji EA (2013) Egg quality traits of indigenous and exotic chickens as influenced by specific genes. Journal of Biology, Agriculture and Healthcare, 3: 53-57.

Islam MS and Dutta RK (2010) Egg quality of indigenous, exotic and crossbred chickens (Gallus domestics L.,) in Rajshahi, Bangladesh Journal of Life Earth Science, 5: 63-67.

Monira KN, Salahuddin M and Miah G (2003) Effect of breed and holding period on egg quality characteristics of chicken. International Journal of Poultry Science, 2: 261-263.

Nonga HE, Kajuna FF, Ngowi HA and Karimuribo ED (2010) Physical egg quality characteristics of free-range local chickens in Morogoro municipality, Tanzania. Livestock Research for Rural Development, 22: 218).

Rajkumar U, Sharma RP, Rajaravindra KS, Niranjan M, Reddy BLN, Bhattacharya TK and Chatterjee RN (2009) Effect of genotype and age on egg qualityt in naked neck chicken under tropical climate from India. International Journal of Poultry Science, 8: 1151-1155.

Silversides PG and Scott TA (2001) Effect of storage and layer age on quality of eggs from two lines of hens. Poultry Science, 80: 1240- 1245

Sonaiya EB and Swan SEJ (2004) Marketing in Small-scale poultry production- technical guide. FAO, Rome.

SPSS Inc. (2007). SPSS for Windows, Version 16.0, Chicago, SPSS Inc.

Stadelman WJ and Cotterill OJ (1995) Egg Science and Technology. $4^{\text {th }}$ Edn. Food Products Press. An Imprint of the Haworth Press. INC: New York, London.

Tharrington JB, Curtise PA, Jones FT and Anderson KE (1999) Comparison of physical quality and composition of eggs from historic strains of single comb White Leghorn chickens. Poultry Science, 78: 591-584.

Yakubu A, Ogahm DM and Barde RE (2008) Productivity and egg quality characteristics of free range naked neck and normal feathered Nigerian indigenous chickens. International Journal of Poultry Science, 7 (6) : 579-585. 